\title{
UPAYA MENINGKATKAN AKTIVITAS DAN PRESTASI BELAJAR BAHASA INDONESIA MENEMUKAN GAGASAN UTAMA PARAGRAF MELALUI MODEL JIGSAW SISWA VII A SMPN 1 JENAR SRAGEN
}

\author{
Sarji \\ Guru Bahasa Indonesia SMPN 1 Jenar, Kabupaten Sragen \\ Adji196418@gmail.com
}

\begin{abstract}
This research was purposed for improving students' learning activity and achievement on the subject of Bahasa Indonesia through the activity of finding main idea of paragraph for class VII A students of SMPN 1 Jenar on the year of 2016/2017 using Jigsaw model of cooperative learning. The subjects of this research were 30 students which consisted of 18 male students and 12 female students. This research was conducted for 4 months starting on January to April 2017. The research was composed of two cycles in which each of the cycles was devided into four stages; planning, teaching, observing and reflecting. The data of learning activity of finding the main idea of paragraph from the beginning to end were as followed: The starting average of learning activity which was at $43 \%$ was improved to $67 \%$ in cycle I and aimed higher in cycle II touching 90\% average point. The data of learning achievement which started at the average of 66 was improved to 77 in cycle I and 83 in cycle II. Based on the research theory and learning data obtained, this research concluded that Jigsaw model of cooperative learning succeed to improve students' learning activity and achievement of Bahasa Indonesia subject material in finding the main idea of paragraph conducted on the students of class VII A of SMPN 1 Jenar, Sragen on the year of 2016/2017.
\end{abstract}

Keywords: Jigsaw.Learning Activity.Learning Achievement

\begin{abstract}
Abstrak. Tujuan penelitian adalah untuk meningkatkan aktivitas dan dan prestasi belajar bahasa Indonesia materi menemukan gagasan utama paragraf bagi siswa kelas VII A SMPN 1 Jenar pada semester genap tahun pelajaran 2016/2017 melalui pembelajaran koopertif model Jigsaw. Subjek penelitian adalah siswa yang berjumlah 30 anak, 18 laki-lakidan 12 perempuan. Waktu penelitianselama 4 bulan dari bulan Januari s.d April 2017. Penelitian terdiri dari dua siklus, di mana tiap siklusterdiri dari empat tahap yaitu perencanaan, pelaksanaan tindakan, pengamatan dan refleksi. Data aktivitas belajar menemukan gagasan utama dari kondisi awal sampai kondisi akhir sebagai berikut, Kondisi awal aktivitas belajar rerata43\%, pada siklus I aktivitas belajar rerata $67 \%$, dan siklus II aktivitas belajar rerata 90\%. Data prestasi belajar pada pratindakan rerata 66, pada siklus I rerata 75 dan pada siklus II rerata 83 . Berdasarkan kajian teori dan hasil tindakan dapat disimpulkan bahwapembelajaran kooperatif model jigsaw dapat meningkatkan aktivitas dan prestasi belajar bahasa Indonesia materi menemukan gagasan utama paragraf bagi siswa kelas VII A SMPN 1 Jenar pada semester genap tahun pelajaran 2016/2017
\end{abstract}

Kata kunci: Jigsaw. Akivitas Belajar. Prestasi Belajar. 


\section{Pendahuluan}

\section{A. LatarBelakang Masalah}

Kondisi awal sebelum penelitian dilakukan menunjukkan bahwa aktivitas dan prestasi belajar menemukan gagasan utama paragraf siswa kelas VII A SMPN 1 Jenar pada semester genap tahun 2016/2017 masih rendah belum sesuai yang diharapkan. Berdasarkan hasil pengamatan dan ulangan saat pratindakan, aktivitas dan prestasi belajar menemukan gagasan utama paragraf masih di bawah dari kriteria ketuntasan minimal yang ditetapkan oleh sekolah. Aspek pengamatan yang digunakan untuk mengetahui aktivitas belajar siswa dalam menemukan gagasan utama paragraf antara lain: ketekunan siswa dalam mengikuti pembelajaran, keberanian siswa bertanya, keaktifan siswa berpendapat , dan kerja sama dengan siswa lain dalam kegiatan diskusi. Sedangkan aspek prestasi belajar dalam menemukan gagasan utama paragraf antara lain: ketepatan dalam menemukan kalimat utama,dan ketepatan dalam menemukan gagasan utama paragraf.

Berdasarkan pengamatan saat pratindakan dari 30 jumlah siswa kelas VII A ada 17 siswa atau 57\% aktivitas belajar menemukan gagasan utama suatu paragraf rendah. Sedangkan rerata hasil tes prestasi belajar menemukan gagasan utama paragraf saat pra tindakan adalah 66 masih jauh dari kriteria ketuntasan minimal yang ditetapkan sekolah sebesar 75. Siswa yang memenuhi kriteria ketuntasan hanya ada 12 siswa atau $40 \%$.

Masih rendahnya aktivitas dan pretasi belajar menemukan gagasan utama suatu paragraf pada siswa kelas VII A SMPN 1 Jenar disebabkan oleh peneliti yang belum menerapkan pendekatan pembelajaran yang tepat dan efektif. Peneliti hanya menggunakan metode ceramah dan tanya jawab dalam memberikan materipembelajaranmenemukan gagasan utama paragraf, dilanjutkan dengan memberi contoh paragraf dan menjelaskan bagaimanan cara menemukan kalimat gagasan utama paragraf dan gagasan utama paragraf. Siswa diberi soal teks paragraf kemudian mengerjakan soal berdasarkan contoh yang telah diberikan.Setelah selesai mengerjakan soal, siswa mempresentasikan hasil pekerjaannya. Sedangkan siswa yang lain memberikan tanggapan atas presentasi temannya. Di akhir pertemuan siswa diberi soal untuk menemukan kalimat utama suatu paragraf dan gagasan utama paragraf. Langkah selanjutnya guru memberikan penilaian berdasarkan hasil jawaban siswa.

Dengan adanya masalah tersebut di atas, maka perlu adanya pemecahan masalah. Pemecahan masalah tersebut perlu adanya suatu tindakan nyata yang harus dilakukan oleh peneliti sendiri yaitu melalui pembelajaran kooperatif model jigsaw yang dilakukan melalui dua siklus. Hal tersebut dilakukan dalam upaya meningkatkan aktivitas dan prestasi belajar bahasa Indonesia materi menemukan gagasan utama paragraf bagi siswa kelas VII A SMPN 1 Jenar pada semester genap tahun 2016/2017.

Model Jigsaw dikembangkan dan diuji oleh Elliot Arronson dan rekan-rekannya di Universitas Texas, dan kemudian diadaptasi oleh Slavin dan kawan-kawan di Universitas John Hopkin, Sugianto, (2008:43). Menurut Slavin (2005:246) Jigsaw adalah salah satu dari metode-metode kooperatif yang paling fleksibel. Model pembelajaran Jigsaw merupakan salah satu variasi model Collaborative Learning yaitu proses belajar kelompok di mana setiap anggota menyumbangkan informasi, pengalaman, ide, sikap, pendapat, kemampuan, dan keterampilan yang dimilikinya, untuk secara bersama-sama saling meningkatkan pemahaman kepada seluruh anggota.

Pembelajaran kooperatif (Cooperative Learning) adalah pendekatan pembelajaran yang berfokus pada penggunaan kelompok kecil siswa untuk bekerja sama dalam memaksimalkan kondisi belajjar untuk mencapai tujuan belajar, Sugiyanto (2008:35). Sedangkan menurut Suprijono, Agus (2010:54) pembelajaran kooperatif adalah konsep yang lebih luas meliputi semua jenis kerja kelompok termasuk bentuk-bentuk 
yang dipimpin oleh guru atau diarahkan oleh guru.

Menurut Slavin dalam Sugiyanto (2008:43-44) pembelajaran model jigsaw langkah-langkahnya: (1) kelas dibagi menjadi beberapa tim yang anggotanya terdiri 4 atau 5 siswa dengan karakteristik yang heterogen, (2) bahan akademik disajikan kepada siswa dalam bentuk teks, dan setiap siswa bertanggung jawab dengan mempelajari suatu bagian dari bahan akademik tersebut, (3) para anggota dari beberapa tim yang berbeda memiliki tanggung jawab untuk mempelajari suatu bagian akademik yang sama dan selanjutnya berkumpul untuk saling membantu mengkaji bagian bahan tersebut. Kumpulan siswa semacam itu disebut 'kelompok pakar (expert group), (4) selanjutnya para siswa yang berada dalam kelompok pakar kembali ke kelompok semula (home teams) untuk mengajar anggota lain mengenai materi yang telah dipelajari dalam kelompok pakar, (5) setelah dilakukan pertemuan dan diskusi dalam "home teams", para siswa dievaluasi secara individual mengenai bahan yang telah dipelajari.

Sardiman (2001:93) menyatakan bahwa aktivitas belajar adalah seluruh aktivitas siswa dalam proses belajar, mulai dari krgiatan fisik sampai kegiatan psikis. Pada prinsipnya belajar adalah berbuat, tidak ada belajar jika tidak ada aktivitas. Itulah mengapa aktivitas merupakan prinsip yang sangat penting dalam interaksi belajar mengajar,

Soemanto (2006:107) mengemukakan beberapa aktivitas belajar dalam beberapa situasi antara lain: (1) mendengarkan; (2) memandang; (3) meraba, mencium dan mencicipi/mengecap; (4) menulis dan mencatat; (4) membaca; (5) membuat ikhtisar atau ringksan, dan menggarisbawahi; (6) mengamati tabel-tabel, diagram-diagram, dan bagan-bagan; (7) mengamati tabletabel, diagram-diagram, dan bagan-bagan; (8) menyusun peper atau kertas kerja; (9) mengingat; (10) berfikir); (11) latihan atau praktik.

Aktivitas belajar merupakan segala kegiatan yang dilakukan dalam proses interaksi guru dengan siswa dalam rangka mencapai tujuan belajar. Aktivitas yang dimaksud di sini penekanannya pada siswa, karena dengan adanya aktivitas dalam proses pembelajaran akan terciptasituasi belajar aktif.

Dari uraian di atas perlu ditegaskan bahwa aktivitas belajar merupakan segala kegiatan yang dilakukan dalam proses interaksi guru dengan siswa dalam rangka mencapai tujuan belajar. Aktivitas yang dimaksud di sini penekanannya pada siswa, karena dengan adanya aktivitas dalam proses pembelajaran akan tercipta situasi belajar aktif..

Menurut Djamarah (1994:19) prestasi adalah hasil dari suatu kegiatan yang telah dikerjakan, diciptakan baik secara individu maupun secara kelompok. Sedangkan dalam Kamus Umum Bahasa Indonesia (1995:787) prestasi adalah hasil yang telah dicapai (dari yang telah diakukan, dikerjakan, dan sebagainya

Prestasibelajar merupakan penguasaan pengetahuan atau keterampilan yang dikembangkan oleh mata pelajaran, lazimnya ditunjukkan dengan nilai tes atau angka nilai yang diberikan oleh guru. Tes prestasi diberikan sesudah orang yang dimaksud mempelajari hal-hal sesuai dengan apa yang diteskan, Mulyasa (2000: 100). Ahmad Sabri (2005: 50)menyatakan bahwa prestasi belajar dipengaruhi oleh: a. Faktor intern, meliputi: tujuan, minat, aktivitas, kecakapan,kebiasaan belajarserta penguasaan bahanpelajaran;b. Faktor ekstern,meliputi: Faktor lingkungan sekolah,berupacaramemberipelajaran.

Berdasarkan uraian di atas dapat disimpulkan hakikatprestasi belajar adalah hasil atau taraf kemampuan yang telah dicapai siswa setelah mengikuti proses belajar mengajar dalam waktu tertentu baik berupa perubahan tingkah laku, keterampilan dan pengetahuan dan kemudian akan diukur dan dinilai yang kemudian diwujudkan dalam angka atau pernyataan

Menurut Kosasih (2003:40) Sebuah karangan dibangun dari satuatau kumpulan paragraf. Paragraf merupakan kumpulan 
kalimat yang saling berkaitan eratuntuk membahas satu permasalahan. Oleh karena itu, paragraf umumnya terdiri dari sejumlah kalimat. Kalimat-kalimat itu saling bertalian untuk mengungkapkan sebuah gagasan tertentu. Sedangkan menurut Arifin (2004:113), paragraf adalah seperangkat kalimat yang membicarakan suatu gagasan atau topik.

Sebuah paragraf yang baik harus memiliki satu permasalahan yang disebut dengan gagasan utama.Gagasan utama adalah gagasan yang menjadi dasar pengembangan sebuah paragraf. Sedangkan Mustakim (1994:115) gagasan utama merupakan masalah yang diungkapkan dalam sebuah paragraf dan dalam sebuah paragraf hanya ada satu masalah

Gagasan Utama atau ide pokok merupakan pernyataan yang menjadi inti pembahasan. Gagasan utama terdapat pada kalimat utama dalam setiap paragraf. Menurut Arifin (2004:121), kalimat utama merupakan kalimatyangberisi topik yang dibicarakan pengarang".

\section{B. Metode}

Penelitian tindakan kelas ini dilaksakan di kelas VII A SMPN 1 Jenar Tahun Pelajaran 2016/2017 beralamat di Desa Dawung, Kelurahan Dawung, Kecamatan Jenar, Kabupaten Sragen yang berjumlah 30 siswa terdiri sari 18 laki-laki dan 12 perempuanPenelitian dilakukan selama 4 bulan yaitu mulai bulan Januari 2017 sampai dengan bulan April 2017.

Data yang diambil dalam penelitian tindakan kelas ini meliputi: (1) data aktivitas belajar menemukan gagasan utamaparagraf kondisi awal,(2) data prestasi belajar menemukan gagasan utama paragraf kondisi awal, (3) data aktivitas belajar menemukan gagasan utama paragraf siklus I,(4) data prestasi belajar menemukan gagasan utama paragraf siklus 1, (5) data aktivitas belajar menemukan gagasan utama paragraf siklus II, (6) data prestasi belajar menemukan gagasan utama paragraf siklus II.
Data aktivitas belajar menemukan gagasan utama paragrafkondisi awal dikumpulkan menggunakan teknik dokumentasi dan alatnya berupa dokumen catatan jurnal pembelajaran. Data prestasi belajar menemukan gagasan pokok kondisi awal dikumpulkan menggunakan teknik dokumentasi dan alatnya berupa dokumen catatan daftar nilai.Data aktivitas belajar menemukan gagasan utama suatu paragraf siklus I dikumpulkan menggunakan teknik observasi atau pengamatan dan alatnya berupa lembar observasi. Data prestasi belajar menemukan gagasan utama suatu paragraf siklus I dikumpulkan menggunakan tes tertulis dan alatnya berupa soal tes tertulis.Data aktivitas belajar menemukan gagasan utama paragraf siklus II dikumpulkan menggunakan teknik observasi atau pengamatan dan alatnya berupa lembar observasi.Data presatasi belajar menemukan gagasan utama suatu paragraf siklus II dikumpulkan menggunakan tes tertulis dan alatnya berupa soal tes tertulis.

Validasi data aktivitas belajar menemukan gagasan utama paragraf siklus I maupun data aktivitas belajar menemukan gagasan utama paragraf silklus II diperoleh menggunakan teknik observasi agar diperoleh data yang valid perlu melibatkan observer atau teman sejawat yang dikenal dengan kolaborasi. Sedangkan data prestasi belajar menemukan gagasan utama paragraf siklus I maupun data prestasi belajar menemukan gagasan utama paragraf siklus II yang dikumpulkan menggunakan teknik tes tertulis agar datanya valid butir soalnya perlu divalidasi dengan cara membuat kisi-kisi sebelum butir soal disusun.

Data aktivitas belajar menemukan gagasan utama paragraf kondisi awal, data aktivitas belajar menemukan gagasan utama paragrafsiklus I, dan data aktivitas belajar menemukan gagasan utama paragraf siklus II. Ketiga data tersebut dianalisis menggunakan teknik diskriptik komparatif dilanjutkan analisis kritis dengan cara merefleksi diskriptik komparatif yaitu membandingkan secara diskripsi data aktivitas belajar menemukan 
gagasan utama paragraf kondisi awal dengan data aktivitas belajar menemukan gagasan utama paragraf siklus I, membandingkan data aktivitas belajar menemukan gagasan utama paragraf siklus I dengan data aktivitas belajar menemukan gagasan utama paragraf siklus II dan membandingkan data aktivitas belajar menemukan gagasan utama paragraf kondisi awal dan data aktivitas belajar menemukan gagasan utama paragraf kondisi akhir.

Data prestasi belajar menemukan gagasan utama paragraf kondisi awal, data prestasi belajar menemukan gagasan utama paragraf siklus I dan data prestasi belajar menemukan gagasan utama paragraf siklus II. Ketiga data tersebut dianalisis menggunakan teknik diskriptik komparatif dilanjutkan analisis kritis dengan cara merefleksi diskriptik komparatif yanitu membandingkan membandingkan secara diskripsi data prestasi belajar menemukan gagasan utama suatu paragraf kondisi awal dengan data prestasi belajar menemukan gagasan utama paragraf siklus I, membandingkan data prestasi belajar menemukan gagasan utama paragraf siklus I dengan prestasi belajar menemukan gagasan utama paragraf siklus II dan membandingkan data prestasi belajar menemukan gagasan utama paragraf kondisi awal dan data prestasi belajar menemukan gagasan utama paragraf kondisi akhir.

\section{Hasil Penelitian Dan Pembahasan}

\section{A. Deskripsi Data KondisiAwal}

Data aktivitas belajar menemukan gagasan utama paragraf pada kondisi awalmenunjukkankriteriarendah, dari30 siswa kelas VII A rerata aktivitas belajar yaitu sebesar43\%.Ada 18 siswa yang aktivitasnya rendah. Aspek aktivitas belajar yang diamati antara lain: (1) ketekunan siswa dalam mengikuti pembelajaran, (2) keaktifan siswa bertanya, (3) keaktifan siswa berperndapat, (4) kerja sama siswa dengan yang lain dalam berdiskusi. Sedangkan deskripsi dataprestasi belajarbelajar menemukan gagasan utama paragraf padakondisiawal antara lain : nilai terndah 45 , milai tertinggi 80 , nilai rerata
66, jumlah siswa tuntas 12 anak (37\%) dan jumlah siswa tidak tuntas ada 18 anak (63\%).

\section{Deskripsi Data Siklus I}

Hasil pengamatan terhadap aktivitas siswa pada siklus I selama mengikuti pembelajaran menemukan gagasan utama paragraf meliputi: (1) ketekunan siswa dalam mengikuti pembelajaran, (2) keaktifan siswa bertanya, (3) keaktifan siswa berperndapat, (4) kerja sama siswa dengan yang lain dalam berdiskusi. Dari30 siswa kelas VII A, rerata aktivitas belajar meningkat menjadi sebesar67\%. Masih ada 10 anak yang aktivitanya rendah.Data prestasi belajar menemuikan gagasan utama paragrafsiklus I dikumpulkan menggunakantekniktes tertulis dan alatnya berupa soal tes tertulis. Data prestasi belajar padasiklus Iantara lain : nilai terndah50, milai tertinggi 95, nilai rerata 75 , jumlah siswa tuntas 20 anak (67\%) dan jumlah siswa tidak tuntas ada 10 anak (33\%).

\section{Deskripsi Data Siklus II}

Hasil pengamatan terhadap aktivitas siswa pada siklus II selama mengikuti pembelajaran menemukan gagasan utama paragraf meliputi: (1) ketekunan siswa dalam mengikuti pembelajaran, (2) keaktifan siswa bertanya, (3) keaktifan siswa berperndapat, (4) kerja sama siswa dengan yang lain dalam berdiskusi. Dari30 siswa kelas VII A, rerata aktivitas belajar sangat tinggi yaitu sebesar90\%. Siswa yang aktivitasnya rfendah tinggal 3 anak. Data prestasi belajar menemuikan gagasan utama paragrafsiklus II dikumpulkan menggunakantekniktes tertulis dan alatnya berupa soal tes tertulis. Hasil rekapitulasi prestasi belajar siklus II antara lain : nilai terndah65, milai tertinggi 95 , nilai rerata 83 , jumlah siswa tuntas 28 anak (93\%) dan jumlah siswa tidak tuntas ada 2 anak $(7 \%)$.

\section{B. Hasil Tindakan}

Setelah diadakan tindakan pada siklus I dan siklus II, aktivitas belajar menemukan gagasan utama paragraf yangmeliputi: 
(1) ketekunan siswa dalam mengikuti pembelajaran, (2) keaktifan siswa bertanya, (3) keaktifan siswa berperndapat, (4) kerja sama siswa dengan yang lain dalam berdiskusi mengalami kenaikan yang signifikan . Pada kondisi pratindakan rerata aktivitas belajar $43 \%$, pada siklus I rerata aktivitas $67 \%$, dan pada siklus II rerata aktivitas belajar $90 \%$.Sedangkan prestasi belajar setelah tindakan mengalami kenaikan.Hasil prestasi belajar menemukan gagasan utama paragraf saat pratindakan, siklus I dan siklus II adalah sebagai berikut:

\begin{tabular}{clccc}
\hline No. & \multicolumn{1}{c}{ Uraian } & $\begin{array}{c}\text { Hasil } \\
\text { Pratindakan }\end{array}$ & $\begin{array}{c}\text { Hasil } \\
\text { Siklus I }\end{array}$ & $\begin{array}{c}\text { Hasil } \\
\text { Siklus II }\end{array}$ \\
\hline 1. & Nilai rerata & 66 & 75 & 83 \\
2 & Nilai terendah & 45 & 50 & 65 \\
3. & Nilai tertinggi & 88 & 95 & 95 \\
4. & Jumlah tuntas belajar & 12 anak & 20 anak & 28 anak \\
5 & Jumlah tidak tuntas & 18 anak & 10 anak & 2 anak \\
\hline
\end{tabular}

\section{Pembahasan}

Aktifitas belajar pada kondisi awal, menunjukkan bahwa dalam pembelajaran menemukan gagasan utama paragraf masih sangat rendah, yaitu rerata sebesar $43 \%$. Siswa yang aktivitanya rendah ada 17 anak Sedangkan prestasi belajarpada kondisi awal juga masih rendah dengan rerata nilai sebesar 66. Siswa yang belum tuntas sebanyak 18 anak Rendahnya aktivitas dan prestasi belajar tersebut disebabkan karena guru belum menggunakan model pembelajaran yang tepat sehingga suasana kelas kurang bersemangat dan membosankan.

Pada siklus I guru mulai menggunakan pembelajarankooperatifmodeljigsaw.Suasana belajar di kelasmenjadilebihmenyenangkan danlebih bersemangat.Rerata aktifitas belajar siswa semakin meningkat, yaitu sebesar $67 \%$.Siswa yang aktivitasnya rendah berkurang menjadi 13 anak. Sedangkan prestasi belajar pada siklus I juga semakin meningkat. Rerata prestasi belajar menjadi75\%. Siswa yang belum tuntas tinggal 10 anak. Hasil refleksi pelaksanaan siklus I merkomendasikan untuk perbaikanperencanaan pembelajaran

Pada siklus II kekurangan yang ada pada siklus I diperbaiki.guru dapat melaksanakan pembelajaransesuai rencana. Suasanapembelajaran di kelas meningkat secara signifikan, kelas menjadi aktif dan menyenangkan. Interaksi antarsiswa terjalin dengan baik. Guru berperan sebagai fasilitator dalam pembelajaran sehingga siswa semakin aktif dalam berdiskusi dalam menemukan gagasan utama paragraf. Rerata aktifitas belajar meningkat menjadi $90 \%$. Sisw yang aktivitasnya rendah tinggal 3 anak. Sedangkan rerata prestasi belajar meningkat menjadi 83.Siswa yang tidak tuntas belajar tinggal 2 anak dari jumlah siswa 30 anak.

Berdasarkan realitas menunjukkan bahwa terjadinya peningkatan aktifitas dan prestasi belajar menemukan gagasan utama paragraf melalui penerapan pembelajaran kooperatif model jigsaw.

\section{Simpulan}

Melalui penerapan pembelajaran kooperatif model jigsaw dapat meningkatkan aktivitas belajar dalam menemukan gagasan utama paragraf bagi siswa kelas VII ASMPN 1 Jenar pada semester genap tahun pelajaran 2016/2017 dari kondisi awal rerata aktivitas belajar rendah yaitu sebesar $43 \%$ ke kondisi akhir aktivitas belajar tinggi, yaitu sebesar 90\% Sedangkan prestasi belajar bagi siswa kelas VII A meningkat dari kondisi awal prestasi belajar nilai rata-rata $66 \mathrm{ke}$ kondisi akhir prestasi belajarnilai rata-rata 83, maka kesimpulannya melalui penerapan pembelajaran kooperatif model jigsaw dapat 
meningkatkan aktivitas dan prestasi belajar hendaknya dapat memanfaatkan dan memilih dalam menemukan gagasan utama paragraf metode, teknik, maupun model pembelajaran bagi siswa kelas VII ASMPN 1 Jenar pada yang tepat dan sesuai dengan materi semester genap tahun pelajaran 2016/2017 pembelajaran agar proses pembelajaran baik teoritik maupun empirik. menjadi aktif, efektif dan menyenangkan.

\section{Saran}

Untuk mengatasi permasalahan pembelajaran bahasa Indonesia, guru Guru sebaiknya dalam kegiatan pembelajaran menemukan gagasan utama paragraf menggunakanmodel pembelajaran Jigsaw..

\section{Daftar Pustaka}

Ahmad,Sabri.2005.StrategiBelajarMengajardanMicroTeaching.Jakarta: QuantumTeaching.

Arifin, Zaenaldan S. Amran Tasai. 2004. Cermat BerbahasaIndonesia UntukBerbahasa. Jakarta: PT Gramedia Pustaka Utama.

Djamarah, Syaiful Bahri. 1994. Prestasi Belajar dan kompetensi Guru. Surabaya: Usaha Nasional.

E. Kosasih. 2003. Ketatabahasaan dan Kesusastraan, Cermat Berbahasa Indonesia. Bandung: YramaWidya

Mulyasa.2000. KurikulumBerbasisKompetensi.Bandung:PT Rosdakarya

Mustakim. 1994. Membina Kemampuan Berbahasa: Panduan ke Arah Kemahiran

Sardiman. 2001. Interaksi dan Motivasi Belajar Mengajar, Jakarta: Raja Grasindo Persada

Slameto. 2003. Belajar dan Faktor-Faktor yang Mempengaruhinya. Jakarta: Rineka Cipta.

Soemanto, Wasty. 2006. Psikologi Pendidikan. Jakarta: Rineka Cipta.

Sugiyanto. 2008. Model-Model Pembelajaran. Panitia Sertifikasi Guru Rayon 13: Surakarta

Suprijono, Agus. 2010. Cooperative Learning Teori \& Aplikasi Paikem. Yogyakarta: Pustaka Pelajar 